\title{
Penegakan Hukum Terhadap Tindak Pidana Pertambangan Mineral dan Batubara Ilegal di Kota Cirebon
}

\author{
Muhammad Agus Fajar Syaefudin', Fajar Ari Sudewo² \\ Universitas Pancasakti Tegal \\ Jalan Halmahera KM 1 Mintaragen Tegal \\ devimuslimah278@gmail.com agusfajar248@gmail.com, fajarari_sudewo@upstegal.ac.id \\ Masuk: 2 Mei 2020; Diterima: 27 Mei 2020; Terbit: 29 Mei 2020. \\ DOI: $10.24905 /$ diktum.v8i1.81
}

\begin{abstract}
Research objectives for analyzing law enforcement on illegal sand mining crimes in Cirebon City .In fact there are still many mining business activities that do not have mining business licenses. This research uses Normative Research Method which is library material which is basic data in (science) which is classified as secondary data and uses the type of library research (Library Research). This study discusses the problem of the impacts of mining activities without a permit covering positive and negative impacts on the surrounding community living around the mine and law enforcement against mining crimes without permission / illegal mining that has been regulated in Article 158 of the Mining Law, so that those carried out by the perpetrators do not have a permit, the authorized party carries out law enforcement in accordance with the provisions of the legislation in force.
\end{abstract}

Keywords: Illegal Mining, Impacts of Activities, Law Enforcement

\begin{abstract}
Abstrak
Tujuan penelitian untuk menganalisa penegakan hokum pada tindak pidana penambangan pasir illegal di kota Cirebon. Indonesia adalah negara yang kaya akan bahan galian (tambang),bahan galian tambang itu meliputi : perak, tambang, gas bumi dan batu bara, oleh karena itu sebelum melakukan kegiatan usaha pertambangan harus memiliki izin yang diatur dalam Pasal 1 ayat (7) Undang-Undang Nomor 4 Tahun 2009 Tentang Mineral dan Batubara. Pada kenyataannya masih banyak kegiatan usaha pertambangan yang tidak memiliki izin usaha pertambangan. Penelitian ini menggunakan Metode Penelitian Normatif adalah bahan pustaka yang merupakan data dasar dalam (ilmu) yang digolongkan sebagai data sekunder dan menggunakan jenis penelitian kepustakaan (Library Reseach). Penelitian ini membahas suatu permasalahan dampak kegiatan pertambangan tanpa izin mencangkup dampak positif dan negatif bagi masyarakat sekitar yang tinggal disekitar pertambangan dan Penegakan hukum terhadap tindak pidana pertambangan tanpa izin/ilegal mining yang sudah diatur dalam Pasal 158 Undang-Undang Pertambangan, sehingga yang dilakukan oleh pelaku tidak memiliki izin maka pihak yang berwenanglah yang melakukan penegakan hukum sesuai ketentuan peraturan perundangundangan yang berlaku.
\end{abstract}

Kata Kunci : Pertambangan Ilegal, Dampak Kegiatan,Penegakan Hukum. 


\section{A. Pendahuluan}

Pengelolaan sumber daya alam merupakan suatu kegiatan manusia dalam menggali, mengelola sumber daya, dan kekayaan alam dengan sebaik-baiknya yang meliputi air, udara, tanah bertujuan untuk kemakmuran rakyat, sebagaimana diatur dalam Pasal 33 ayat (3) Undang-Undang Dasar Republik Indonesia 1945 menyebutkan bahwa bumi, air dan kekayaan alam yang terkandung di dalamnya dikuasai oleh negara dan untuk digunakan sebagai kemakmuran rakyat. Tercapainya kesejahteraan dan kemakmuran rakyat Indonesia, maka dilaksanakannya berbagai macam kegiatan produksi dan usaha untuk menunjang pembangunan. Kegiatan usaha pertambangan untuk pembangunan di Indonesia adalah sektor pertambangan. ${ }^{1}$ Indonesia merupakan negara yang kaya akan bahan galian (tambang). Bahan galian itu, meliputi perak, emas, minyak, tembaga, gas bumi, dan batubara.

Mineral dan Batubara dalam wilayah pertambangan Indonesia merupakan kekayaan alam tak terbarukan sebagai karunia Tuhan Yang Maha Esa mempunyai peranan penting dalam kehidupan masyarakat, maka pengelolaannya harus dikuasai oleh negara untuk memberi nilai tambah, bagi perekonomian nasional dalam kegiatan usaha pertambangan Mineral dan Batubara untuk mencapai kesejahteraan dan kemakuran rakyat secara adil.

Wilayah yang mempunyai potensi Pertambangan adalah Kota Cirebon tepatnya di Kelurahan Argasunya, Kecamatan Harjamukti, Kota Cirebon, Provinsi Jawa Barat. Secara Geografis Kota Cirebon terletak pada $6^{\circ} 41^{\circ} \mathrm{S} 108^{\circ} 33 \mathrm{E} /$ $6.683^{\circ} \mathrm{S} 108.550^{\circ}$ E. Pantai Utara Pulau Jawa, pada bagian timur Jawa Barat, yang mengarah dari barat ke timur sejauh 8 kilometer, dan dari Utara ke Selatan 11 kilometer dengan ketinggian dari permukaan laut 5 meter. Kota Cirebon dapat

${ }^{1}$ Robby Surya Rusmana, Perizinan Pertambangan Rakyat dan Pengawasan di Kabupaten Pesisir Barat, Lampung:Universitas Lampung, 2017 .hlm 1. 
ditempuh melalui jalan darat perkiraan dengan jarak $130 \mathrm{~km}$ dari arah Kota Bandung dan jarak 258 km dari arah Kota Jakarta. Kota Cirebon termasuk daerah iklim tropis, dengan suhu udara minumum rata-rata $22,3{ }^{\circ} \mathrm{C}$ dan maksimum ratarata $33,0^{\circ} \mathrm{C}$ dan banyaknya curah hujan $1.351 \mathrm{~mm}$ per tahun dengan hari hujan 86 hari. $^{2}$

Kota Cirebon memiliki daerah yang sebagian tanah subur dan sebagian kurang produktif disebabkan tanah pantai yang semakin luas akibat endapan sungai-sungai. Tanah di Kota Cirebon adalah tanah jenis regosal yang berasal dari endapan lava dan piroklasik seperti pasir, tanah liat, tupa, lempung, kerikil dan breksi lumpur. Secara umum tanah yang tersebar di Kota Cirebon relatif mudah untuk pengembangan berbagai macam jenis misalnya di sektor Pertambangan.

Luas wilayah yang dimiliki Kota Cirebon adalah sebagian dari kekayaan sumber daya alam yang sangat besar. Potensi Pertambangan di Kota Ciebon adalah mineral bukan logam dan batuan. Fakta tersebut menarik minat untuk para pelaku usaha, masyarakat sekitar dan masyarakat di luar Kota Cirebon untuk memanfaatkan dan mengelola hasil bahan galian tambang, para pelaku usaha dari skala kecil menengah sampai menengah ke atas untuk tertarik melakukan kegiatan pertambangan dikarenakan bisnis pertambangan sangat menguntungkan untuk para pelaku usaha.

Sebelum melakukan kegiatan usaha pertambangan pasir dan tanah urugan memiliki izin terlebih dahulu, setiap usaha pertambangan harus mempunyai izin yang sebagaimana Diatur dalam Pasal 1 ayat (7) Undang-Undang Nomor 4 Tahun 2009 tentang Pertambangan Mineral dan Batubara “ Izin Usaha Pertambangan (IUP) merupakan izin yang diberi kan untuk melakukan usaha pertambangan di dalam sektor pertambangan mineral dan batubara.

\footnotetext{
${ }^{2}$ Pemerintah Kota Cirebon "Letak Geografis", diakses dari https://id.m.wikipedia.org,diakses, pada hari Rabu , tanggal 16 Oktober 2019, pada pukul 22.02 WIB.
} 
Pada kenyataannya masih banyak kegiatan usaha pertambangan Mineral dan Batubara yang tidak memiliki izin usaha pertambangan. Terdapat dampak negatif yang disebabkan oleh kegiatan pertambangan mineral dan batubara pada pertambangan pasir dan tanah urugan tanpa izin yaitu : rusaknya lingkungan hidup akibat wilayah yang menjadi area pertambangan akan terkikis sehingga menyebabkan erosi, limbah hasil pengolahan tambang juga dapat mencemari lingkungan, kegiatan industri yang menggunakan bahan bakar fosil menghasilkan $\mathrm{CO} 2$ yang dapat menimbulkan efek rumah kaca dan pemanasan global, menurunnya kualitas hidup penduduk lokal. Untuk mengatasi dampak negatif tersebut, setiap perusahaan harus memiliki tanggung jawab sosial atau Corporate Social Responsbility (CSR). CSR harus diterapkan dengan prinsip pembangunan berkelanjutan. Prinsip pembangunan berkelanjutan adalah memenuhi kebutuhan sekarang tanpa harus mengorbankan kebutuhan generasi masa depan. ${ }^{3}$

Namun terdapat masalah yang harus diperhatikan oleh pemerintah, yaitu masalah penambangan ilegal. Penambangan ilegal dilakukan tanpa izin, prosedur operasional, dan aturan dari pemerintah. Hal ini membuat kerugian bagi negara karena mengeksploitasi sumber daya alam secara ilegal, mendistribusikan, dan menjual hasil tambangnya secara ilegal, sehingga terhindar dari pajak. Oleh karena itu, pemerintah harus menerapkan aturan yang tegas terhadap para pihak yang melakukan penambangan ilegal.

Pertambangan ilegal kerap sekali dilakukan di Kota Cirebon. Salah satu kasus yang sangat menyita perhatian publik adalah Pertambangan Pasir dan Tanah Urugan di Kota Cirebon pada tahun 2019. Tindakan Pemerintah membuat

\footnotetext{
${ }^{3}$ Marina Ika Sari, Dampak Positif dan Negatif Industri Pertambangan di Indonesia, diakses dari http://www.kompasiana.com/marianaikasari/dampak-positif-dan-negatif-industri-pertambangan-diindonesia_5528d386f17e61780e8b457a, pada hari rabu, tanggal 11 Desember 2019. Pada pukul 21:21 WIB.
} 
sebuah aturan dalam upaya perizinan pertambangan mineral dan batubara. Maka para pelaku usaha pertambangan Mineral dan Batubara yang telah memperoleh izin usaha pertambangan juga tak luput dari pengawasan pemerintah dan kontrol dari para aparatur pemerintah yang berwenang karena bisa saja menyebabkan kerusakan Lingkungan Hidup yang diakibatkan dari kegiatan pertambangan Pasir dan Tanah Urugan yang dilakukan oleh pemilik Izin Usaha Pertambangan secara ilegal. Sehingga perlu diadakannya penelitian lebih lanjut untuk mengetahui permasalahan tersebut.

\section{B. Rumusan Masalah}

1. Bagaimana Dampak Kegiatan Pertambangan Mineral dan Batubara Ilegal di Kota Cirebon?

2. Bagaimana Penegakkan Hukum Terhadap Tindak Pidana Pertambangan Mineral dan Batubara Perizinan Ilegal diKota Cirebon?

\section{Metode Penelitian}

\section{Fokus Penelitian}

Penelitian ini menggunakan Metode Penelitian Normatif penelitian hukum normatif adalah bahan pustaka yang merupakan data dasar dalam (ilmu) penelitian yang digolongkan sebagai data sekunder. ${ }^{4}$ Alasan memilih metode ini karena berkaita dengan penelitian sebelumnya mengenai tindak pidana penambangan pasir yang terjadi di Cirebon.

\section{Jenis Penelitian}

Penerlitian ini merupakan jenis penelitian kepustakaan (Library Reseach) digolongkan sebagai data sekunder. Yang dilaksanakan dengan menggunakan literatur (kepustakaan), baik berupa surat-surat pribadi, buku-buku, catatan,

\footnotetext{
${ }^{4}$ Soerjono Soekanto dan Sri Mamudji, Penelitian Hukum Normatif Suatu Tinjauan Singkat, Jakarta:Pt RajaGrafindo Persada, 2009.hlm.24
} 
laporan hasil penelitian terdahulu, sampai pada dokumen-dokumen resmi yang dikeluarkan oleh pemerintah. ${ }^{5}$

\section{Pendekatan Penelitian}

Pada penelitian ini menggunakan jenis pendekatan penelitian secara normatif, dimana Penelitian Normatif seringkali disebut dengan penelitian doctrinal yaitu objek penelitiannya adalah dokumen perundang-undangan dan bahan pustaka dan bagaimana seorang peneliti menyusun, merumuskan masalah penelitiannya secara tepat dan tajam, serta peneliti memilih metode untuk menentukan langkah-langkahnya dan bagaimana melakukan perumusan dalam membangun teorinya. ${ }^{6}$

\section{Jenis Data}

Jenis penelitian ini adalah penelitian hukum normatif yuridis (normative legal reserch) yaitu penelitian yang dilakukan dengan cara melakukan pengkajian perundang-undangan yang berlaku dan diterapkan terhadap suatu permasalahan hukum tertentu. ${ }^{7}$

\section{Sumber Data}

Sumber data yang akan digunakan dalam penelitian ini adalah Data Primer dan Data Sekunder yang didefinisikan sebagai berikut:

\section{a) Data Primer}

Data Primer yaitu data yang diperoleh langsung dari sumbernya, baik melalui wawancara, observasi maupun laporan dalam bentuk dokumen tidak resmi yang kemudian diolah oleh peneliti.

\section{b) Data Sekunder}

Data Sekunder yaitu data yang diperoleh dari dokumen-dokumen resmi, buku-buku yang berhubungan dengan objek penelitian, hasil penelitian

\footnotetext{
${ }^{5}$ Ibid.hlm24

${ }^{6}$ Bahder Johan Nasution,Metode Penelitian Hukum,Bandung:Mandar Maju, 2008.hlm. 88.

7 Soerjono Soekanto dan H. Abdurrahman, Metode Penelitian Hukum, Jakarta:Rineka Cipta, 2003.hlm.56.
} 
dalam bentuk laporan, skripsi, tesis, disertasi, dan peraturan perundangundangan. Selanjutnya data sekunder dapat dibagi menjadi :

1) Bahan Hukum Primer

Bahan-bahan hukum yang mengikat terdiri dari peraturan perundangundangan yang terkait dengan objek penelitian, antara lain :

a) Undang-Undang Dasar Republik Indonesia Tahun 1945

b) Undang-Undang Nomor 4 Tahun 2009 tentang Pertambangan Mineral dan Batubara

2) Bahan Hukum Sekunder

Bahan hukum sekunder adalah buku-buku dan tulisan ilmiah hukum yang terkait dengan objek penelitian ini. ${ }^{8}$

\section{Metode Analisis Data}

Analisis data yang digunakan dengan penelitian ini adalah Normatif Kualitatif artinya data yang diperoleh dari hasil wawancara berupa katakata, rekaman identik dengan norma-norma tertulis yang relevan dengan Analisis Hukum Tindak Pidana Pertambangan Mineral dan Batubara Ilegal Di Kota Cirebon.

\section{Pembahasan}

\section{Dampak Kegiatan Pertambangan Mineral dan Batubara Ilegal}

Suatu Permasalahan lingkungan hidup semakin hari semakin menunjukkan peningkatan disuatu wilayah Kelurahan Argasunya, Kecamatan Harjamukti, Kota Cirebon, Provinsi Jawa Barat. Hal ini akibat pertambangan mineral dan batubara yang tidak memiliki izin usaha pertambangan oleh karena itu kegiatan atau aktivitas pertambangan juga harus memperhatikan

\footnotetext{
${ }^{8}$ Zainudiin Ali, Metode Penelitian Hukum, Jakarta:Sinar Grafika, 2017.hlm.106
} 
alam dan lingkungan sekitar. Hal ini dapat dilihat dari tata cara pengolahan bahan tambang yang sebagaimana diatur dalam Pasal 2 Undang-Undang Nomor 4 Tahun 2009 tentang Pertambangan Mineral dan Batubara:

"Pertambangan mineral dan/atau batubara dikelola berasaskan:

a. Manfaat, keadilan, dan keseimbangan;

b. Keberpihakan kepada kepentingan bangsa;

c. Partisipasi,transparan, dan akuntabilitas;

d. Berkelanjutan dan berwawasan lingkungan."

Dari suatu permasalahan tersebut mengenai dampak kegiatan pertambangan mineral dan batubara terdapat adanya dampak positif dan dampak negatif yang akan diuraikan di bawah ini mengenai dampak tersebut, yaitu :

a) Dampak Positif Kegiatan Pertambangan Ilegal

Dampak positif adanya suatu kegiatan pertambangan antara lain menciptakan lapangan pertambangan bagi masyarakat, hasil produksi tambang dapat digunakan untuk memenuhi permintaan pasar domestik maupun pasar internasional, sehingga hasil ekspor tambang tersebut dapat meningkatkan suatu pendapatan dan pertumbuhan ekonomi negara. ${ }^{9}$ namun terdapat permasalahan yang harus diperhatikan oleh pemerintah, yaitu suatu permasalahan penambangan Ilegal.

\section{b) Dampak Negatif Kegiatan Pertambangan Ilegal}

\section{1) Dampak Terhadap Udara}

Dampak kegiatan pertambangan yamg terjadi dalam pencemaran udara, dengan adanya pencemaran udara ini maka sangat mengganggu kesehatan masyarakat, sehingga polusi atau pencemaran udara yang

9 Muhammad Amin, 'Dampak Positif dan Negativf Aktivitas Pertambangan', diakses dari https://www.acamedia.edu/16527346/Dampak_positif_dan_negatif_aktivitas_pertambanga, pada hari Senin, Tanggal 06 Januari 2020, Pukul 10:35 WIB. 
kronis sangat berbahaya. Menurut logika udara yang kotor pasti mempengaruhi kerja paru-paru. Peranan polutan ikut andil dalam merangsang penyakit pernafasan seperti influensa, bronchitis dan pneumonia serta penyakit kronis seperti asma sehingga tidak baik untuk kesehatan manusia pada umumnya. ${ }^{10}$

Industri pertambangan mineral dan batubara khususnya di sektor pasir dan tanah urugan yang berada di wilayah argasunya Kec.Harjamukti Kota Cirebon sejauh ini dianggap sebagai salah satu industri yang paling merusak diwilayah tersebut.

\section{2) Dampak Terhadap Air}

Kegiatan penambangan sering kali menggunakan air meskipun sebagian adalah hasil sirkulasi kembali. Mineral-mineral yang mengandung sulfida. Karena kontaknya dengan udara melalui penambangan membentuk asam sulfida yang berkombinasi dengan elemen jejak (trace element). Kondisi ini secara keseluruhan berdampak negatif baik pada air permukaan maupun air tanah. Pencemaran tersebut berasal dari timbunan tailing maupun limbah batuan, dan pada saat proses ledakan tebing yang dapat menaikkan salinitas air.

Dalam kegiatan penambangan pasir dan tanah urugan di wilayah argasunya Kec. Harjamukti Kota Cirebon sejumlah air bersih sekarang ini sudah sangat miris akibat sistem penambangan mineral dan batubara ilegal akibatnya air bersih sulit untuk didapatkan dan kondisi secara tidak langsung sudah menimbulkan efek racun yang dapat mencemari air bersih diwilayah tersebut. Pada tipe penambangan ilegal lebih mudah

10 Murfan" Dampak dan Solusi Pada Pertambangan Batu Bara, diakses dari , dhttps://www.kompasiana.com/murfanhimnur3823/5db6e267097f364a8f78dc12/dampak-dan-solusi-padapertambangan-batu-bara?page=all, pada hari Senin, Tanggal 06 Januari 2020, Pukul 11:40 WIB. 
dijumpai dampak kurangnya air bersih dan menimbulkan racun pada sejumlah makhluk hidup. ${ }^{11}$

\section{3) Dampak Terhadap Kesehatan dan Keselamatan Kerja}

Kegiatan penambangan berkaitan dengan kegiatan transportasi , penyimpanan dan bahan peledak dan bahan kimia racun, bahan radiokatif dikawasan penambangan dan gangguan pernapasan akibat pengaruh debu, kurang lebihnua dampak bagi kesehatan sama halnya dengan dampak terhadap udara yang menimbulkan suatu penyakit seperti influensa, bronchitis dan pneumonia. ${ }^{12}$ Sehingga dari pertambangan juga dapat mengancam keselamatan pekerja tambang dan juga warga yang tinggal di sekitar pertambangan, saat melakukan pertambangan pasir dan tanah urugan para penambang akan menggali dan meledakan tebing kemungkinan akan terjadinya kecelakaan kerja. ${ }^{13}$

Tidak heran banyak pekerja yang kekurangan oksigen dan jika pertambangan tersebut dilanjutkan akan terjadinya longsor akibat tanah tersebut di gali terus menerus jika terus begitu bahaya besar sedang mengancam warga yang tinggal dekat pertambangan seperti banjir bandang hingga tanah longsor.

Menurut Joseph F. Castrilli mendefinisikan dampak dari kegiatan pertambangan, sejak kegiatan ekploitasi sampai dengan kegiatan penetapan tambang (mine clousure). dampak yang disajikan oleh Joseph F.

${ }^{11}$ Meggi Okka Hadi Miharja, Adreas Dwi Setyo dan Herbowo Prasetyo Hadi, Implikasi Hukum Terkait Pertambangan Rakyat Dalam Bidang Minerba Di Indonesia, Journal Faculty Of Law University Sebelas Maret, Vol 103 No. (2015).

${ }^{12}$ Kompasiana, Tambang dan Pengelolaan Lingkungan Ditinjau dari Berbagai Sumber, diakses dari https://www.kompasiana.com/tiur/56a0460314977346058161e/tambang-dan-pengelolaan-lingkunganditinjau-dari-berbagai-sumber?page=2, pada hari senin, tanggal 30 Desember 2019, pukul 12:54 WIB.

13 Ilmu Geografi, 5 Dampak Negatif Pertambangan Terhadap Lingkungan, diakses dari https://ilmugeografi.com/geologi/dampak-negatif-pertambangan-terhadap-lingkungan, pada hari Senin, Tanggal 06 Januari 2020, Pukul 12:12 WIB. 
Castrilli adalah berkaitan dengan dampak kegiatan pertambangan terhadap lingkungan hidup. Dampak lingkungan yang ditimbulkan dan kegiatan pertambangan pada fase kegiatan eksplorasi, meliputi :

1. Terjadinya pembongkaran tanah;

2. Pencemaran polusi di udara

3. Pencemaran limbah

Dampak yang ditimbulkan pada saat dilakukan kegiatan pertambangan (in the mining and miling phase), meliputi :

1. Berkurangnya debit air pada masyarakat lokal;

2. Terjadinya pengikisan (erosi) dan pengendapan (sedimentasi) sungai dan danau. Terjadi kerusakan pada pengaman racun pada penampung air limbah terjadi kerusakan pada penampungan limbah;

3. Pencemaran akibat sianida terhadap air permukaan dan air tanah. ${ }^{14}$

Dampak lainnya akibat adanya kegiatan pertambangan tanpa izin (illegal mining) tersebut yakni adanya ekploitasi dengan cara penggalian yang tidak terkendali sehingga menimbulkan kerusakan lingkungan dan mengganggu keseimbangan ekosistem alam, dimana kegiatan penambangan tersebut dilakukan pada lahan-lahan pertanian atau perkebunan yang memiliki produktivitas tinggi.

Hal tersebut sangat meresahkan masyarakat Kelurahan Argasunya, Kecamatan Harjamukti, Kota Cirebon, Provinsi Jawa Barat, karena kegiatan pertambangan tanpa izin banyak sekali dampak negatif akibat pertambangan ilegal sehingga masyarakat yang tinggal diwilayah tersebut merasa tidak nyaman akibat pertambangan ilegal tersebut misalnya sarana/fasilitas umum serta mengancam rusakya sarana dan

\footnotetext{
${ }^{14}$ Muhamad Yusuf HS, Penegakkan Hukum Terhadap Tindak Pidana Pertambangn Gol.C Tanpa Izin (Studi Kasus Tahun 2014 S/D Tahun 2016 di Kab.Gowa), Makassar: Universitas Hasanuddin,2017. Hlm.44.
} 
prasarana/ infrastruktur, seperti : irigasi, pencemaran lingkungan, pencemaran terhadap udara berupa debu, pencemaran air, dan sebagainya. ${ }^{15}$

\section{Penegakkan Hukum Terhadap Tindak Pidana Pertambangan Mineral dan}

\section{Batubara Perizinan Ilegal}

Penegakkan Hukum adalah proses dilakukannya upaya untuk tegaknya atau berfungsinya norma-norma hukum secara nyata sebagai pedoman perilaku dalam lalu lintas atau hubungan-hubungan hukum dalam kehidupan bermasyarakat dan bernegara. ${ }^{16}$ Upaya penegakan hukum yang dilakukan Pemerintah dalam mengatasi permasalahan lingkungan hidup di Indonesia, baik secara preventif maupun represif tidak terlepas dari terminologi sistem hukum untuk memahami efektivitas berfungsinya hukum dalam mengubah perilaku manusia agar mempunyai kesadaran hukum dalam rangka melindungi dan melestarikan fungsi lingkungan hidup.

Bahwa ketentuan hukum terdiri dari suatu peraturan-peraturan yang menentukan perbuatan apa yang dilarang dan menentukan hukuman apa yang dapat dijatuhkan terhadap yang melakukanya. ${ }^{17}$ Ketentuan hukum pertambangan pasir adalah sistem dan pedoman yang umumnya disokong oleh otoritas pemerintah mengatur tingkah laku atau tindakan manusia dalam melakukan pertambangan pasir dan tanah urugan serta sanksinya yang

\footnotetext{
${ }^{15}$ Muhammad Yusuf HS, Loc cit, hlm.65

16 Jimly Asshidiqie, Guru Besar Hukum Tata Negara Universitas Indonesia, Ketua Dewan Penasihat Asosiasi Hukum Tata Negara dan Administrasi Negara Indonesia:Penegakan Hukum, Universitas Indonesia: Depok.

${ }^{17}$ Lili Rasjidi, Dasar-dasar filsafat dan teori hukum, Bandung : Citra Aditya Bakti, 2001, hlm.58.
} 
dilaksanakan oleh aparat penegak hukum. ${ }^{18}$ Kejahatan pertambangan tanpa izin/ illegal mining merupakan kejahatan pertambangan tanpa izin yang dapat merusak lingkungan hidup dan mengancam kemaslahatan masyarakat sekitar.

Dalam Undang-Undang Pertambangan selain mengenal adanya tindak pidana ilegal mining juga terdapat bermacam-macam tindak pidana lainnya, yang sebagian besar ditujukan kepada pelaku usaha pertambangan, dan hanya satu macam tindak pidana yang ditujukan kepada pejabat penerbit izin dibidang pertambangan oleh karena itu dalam suatu permasalahan bahwa kegiatan pertambangan telah melanggar aturan tindak pidana pertambangan tanpa izin.

Sebagaimana telah diketahui diatas bahwa negara mempunyai hak menguasai atsa bumi, air, dan kekayaan alam yang terkandung didalamnya termasuk tambang. Berdasarkan hal tersebut setiap orang yang akan melakukan kegiatan pertambangan aturan mainnya wajib meminta izin lebih dahulu dari negara/ pemerintah.

Apabila terjadi kegiatan penambangan pelakunya tidak memiliki izin, maka perbuatannya merupakan tindak pidana yang sebagaimana diatur dalam Pasal 158 Undang-Undang Pertambangan yang berbunyi sebagai berikut:

Setiap orang yang melakukan usaha pertambangan tanpa IUP, IPR atau IUPK sebagaimana dimaksud dalam Pasal 37, Pasal 40 ayat (3), Pasal 48, Pasal 67 ayat (1), Pasal 74 ayat (1) atau ayat (5) dipidana dengan pidana penjara

\footnotetext{
${ }^{18} \mathrm{Ibid}, \mathrm{hlm} 58$.
} 
paling lama 10 (sepuluh) tahun dan denda paling banyak Rp.10.000.000.000,00 (sepuluh miliar rupiah). ${ }^{19}$

Berdasarkan uraian diatas, dapat dipahami bahwa kasus pertambangan mineral dan batubara pelaku diduga telah melakukan tindak pidana pertambangan yang diatur dalam Pasal 158 Undang-Undang Nomor 4 Tahun 2009 tentang Pertambangan Mineral dan Batubara dan tindak pidana pertambangan yang dilakukan diatas adalah pertambangan mineral dan batubara disektor pasir dan tanah urugan, sehubungan penambangan yang dilakukan oleh pelaku tidak memiliki izin maka pihak berwenang telah melakukan penegakan hukum sesuai ketentuan peraturan perundangundangan yang berlaku. ${ }^{20}$

\section{E. Simpulan}

Berdasarkan uraian pembahasan diatas, maka penulis menarik simpulan sebagai berikut :

1. Dengan adanya dampak kegiatan pertambangan ilegal dapat dibedakan kedalam dua golongan yakni dampak terhadap lingkungan dan dampak terhadap manusia itu sendiri. Dampak terhadap lingkungan menyangkut tentang dampak terhadap udara, air, tanah, erosi dan ekosistem sehingga memerlukan perbaikan agar tidak terjadinya suatu permasalahan yang sama dan masyarakat maupun pemerintah harus bersama-sama mereboisasi lingkungan yang sudah rusak akibat pertambangan ilegal tersebut. Sedangkan Dampak terhadap manusia itu sendiri dapat mengancam kesehatan dan keselamatan kerja bahkan hilangnya nyawa seseorang, mulai dari adanya

\footnotetext{
${ }^{19}$ Gatot Supramono,"Hukum Pertambangan Mineral Dan Batu Bara Di Indonesia", Jakarta:Rineka Cipta, 2012.hlm 248.

${ }^{20}$ Maizardi, Penegakan Hukum Terhadap Tindak Pidana Pertambangan Batuan Non Logam Pada Tanah Hak Milik Masyarakat,Tesis Pascasarjana Ilmu Hukum, Padang:Universitas Ekasakti Padang,2018,hlm.76.
} 
masalah kesehatan, seperti : gangguan pernafasan dan sebagainya, hingga yang menyangkut nyawa mereka mulai dari tertimbun longsor akibat galian mereka sendiri atau ledakan tebing yang mereka lakukan secara ilegal.

2. Dalam ketentuan oleh penegakan hukum terhadap pidana pertambangan tanpa izin/ ilegal mining sudah diatur dalam Undang-Undang Nomor 4 Tahun 2009 tentang Pertambangan Mineral dan Batubara. Maraknya kejahatan kegiatan pertambangan tanpa izin di Kota Cirebon pelaku telah diduga telah melakukan suatu perbuatan tindak pidana pertambangan tanpa izin dan melanggar Pasal 158 Undang-Undang Pertambangan Mineral dan Batubara, sehubungan penambangan yang dilakukan oleh pelaku tidak memiliki izin maka pihak berwenang telah melalukan penegakan hukum sesuai ketentuan peraturan perundang-undangan yang berlaku.

\section{Daftar Pustaka}

\section{Buku}

Ali Zainudiin, Metode Penelitian Hukum, Jakarta: Sinar Grafika,2007.

Bahder Johan Nasution, Metode Penelitian Hukum, Bandung: Mandar Maju,2008.

Jimly Asshidiqie, Guru Besar Hukum Tata Negara Universitas Indonesia, Ketua Dewan Penasihar Asosiasi Hukum Tata Negara dan Administrasi Negara Indonesia: Penegakan Hukum,Universitas Indonesia, Depok. 2008.

Maizardi, Penegakan Hukum Terhadap Tindak Pidana Pertambangan Batuan Non Logam Pada

Tanah Hak Milik Masyarakat,Tesis Pascasarjana Ilmu Hukum, Padang:Universitas Ekaskti Padang,2008.

Meggi Okka Hadi Miharja, Adress Dwi Setyo dan Herbowo Prasetyo Hadi, Implikasi Hukum

Terkait Pertambangan Rakyat Dalam Bidang Minerba Di Indonesia, Journal Faculty Of Law University Sebelas Maret, Vol 103. (2015). 
Muhamad Yusuf HS, Penegakan Hukum Terhadap Tindak Pidana Pertambagan Gol.C Tanpa Izin (Studi Kasus Tahun 2014 S/D Tahun 2016 di Kab.Gowa). Makassar:Universitas Hasanuddin,2017.

Muhamad Yusuf HS, Penegakan Hukum Terhadap Tindak Pidana Pertambagan Gol.C Tanpa Izin (Studi Kasus Tahun 2014 S/D Tahun 2016 di Kab.Gowa). Makassar:Universitas Hasanuddin,2017.

Rasjidi,Lili,Dasar-daasar Filsafat dan Teori Hukum,Bandung: Citra Aditya Bakti,2001.

Rasjidi,Lili,Dasar-daasar Filsafat dan Teori Hukum,Bandung: Citra Aditya Bakti,2001.

Rusmana,Surya Robby,Perizinan Rakyat dan Pengawasan di Kabupaten Pesisir Barat, Lampung: Universitas Lampung, 2017.

Soekanto, Soerjono dan H.Abdurrahman,Metode Penelitian Hukum,Jakarta : Rineka Cipta, 2003.

Soekanto, Soerjono dan Sri Mamudji, Penilitian Hukum Normatif Suatu Tinjauan Singkat, Jakarta: Pt Raja Grafindo Persada, 2009.

Supramono,Gatot, “Hukum Pertambangan Mineral Dan Batu Bara Di Indonesia', Jakarta:Rineka Cipta,2020.

\section{Peraturan Perundang-Undangan}

Undang-Undang Dasar Republik Indonesia 1945

Undang-Undang Nomor 4 Tahun 2009 tentang Pertambangan Mineral dan Batubara

\section{Sumber Lainnya}

Pemetintah Kota Cirebon"Letak Geografis, di akses dari https://id.m.wikipedia.org, pada hari Rabu, Tanggal 16 Oktober 2019, pada pukul 22:02 WIB.

Marina Ika Sari, Dampak Positif dan Negatif Industri Pertambangan di Indonesia, diakses darihttp://www.kompasiana.com/marianaikasari/dampak-positif-dan-negatif-industripertambangan-di-indonesia_5528d386f17e61780e8b457a, pada hari Rabu, tanggal 11 Desember 2019, pada pukul 21:21 WIB.

Muhamad Amin,"Dampak Positif dan Negatif Aktivitas Pertambangan" diakses dari https://www.acamedia.edu/16527346/Dampak_positif_dan_negatif_aktivitas_pertambanga, pada hari Senin, tanggal 06 Januari 2020, pukul 10:35 WIB. 
Murfan, “Dampak dan Solusi Pada Pertambangan Batu Bara, diakses dari https://www.kompasiana.com/murfanhimnur3823/5db6e267097f364a8f78dc12/dampak-dan-

solusi-pada-pertambangan-batu-bara?page=all, pada hari Senin,tanggal 06 Januari 2020,pukul 11:40 WIB.

Kompasiana,Tambang dan Pengelolaan Lingkungan Hidup Di Tinjau Dari Berbagai Sumber, diakses dari https://www.kompasiana.com/tiur/56a0460314977346058161e/tambang-danpengelolaan-lingkungan-ditinjau-dari-berbagai-sumber?page=2, pada hari Senin, tanggal 30 Desember 2019, pukul 12:54 WIB.

Ilmu Geografi, 4 Dampak Negatif Pertambangan Terhadap Lingkungan, diakses dari https://ilmugeografi.com/geologi/dampak-negatif-pertambangan-terhadap-lingkungan, pada hari Senin, tanggal 06 Januari 2020, pukul 12:12 WIB. 